\begin{tabular}{rr} 
çağdaş & Yaratıcı Drama Dergisi 2018, 13(2), 153-172 \\
drama & www.yader.org \\
\hline
\end{tabular}

\title{
Okul-Gerçek Yaşam ve Sorumluluk Üstlenme İlişkisini Sorgulayan Yeni Bir Drama Yaklaşımı: Komisyon Modeli*
}

Zeki Özen ${ }^{1}$

Ömer Adıgüzel

\begin{tabular}{|c|c|}
\hline Makale Bilgisi & $\ddot{\text { Öz }}$ \\
\hline DOI: $10.21612 /$ yader.2018.012 & $\begin{array}{l}\text { Bu çalışma, drama alanı öncülerinden Dorothy Heathcote'un son dönem drama } \\
\text { yaklaşımlarından olan ve drama alanında yeterince bilinmeyen "Komisyon Model" }\end{array}$ \\
\hline Makale Geçmişi & yaklaşımın tanımlamak, bu tanımdan hareketle bir uygulama örneği geliştirmek ve \\
\hline Geliş tarihi & $\begin{array}{l}\text { uygulama örneğine dahil olan ögrencilerin yaşantılarını komisyon modelin amaçları } \\
\text { doğrultusunda analiz etmek amacıvla gerceklestirilmistir. Arastırma nitel arastırma }\end{array}$ \\
\hline 15.06.2018 & $\begin{array}{l}\text { desenlerinden eylem araştırması deseniyle yapılandırllmıştır. Araştırma grubunu, } \\
\text { Ankara Üniversitesi Eğitim Bilimleri Fakültesinde 2015-2016 eğitim ögretim } \\
\text { döneminde farklı anabilim dallarında ögrenim görmekte olan ögretmen adayları } \\
\text { oluşturmuştur. Uygulama sürecinde gözlem, görüşme, görsel sunumlar,yansitıcı özetler, }\end{array}$ \\
\hline Anahtar Sözcükler & ses kaydı ve video kaydı yolu ile veriler toplanmıştır. Araştırma sürecinde toplanan \\
\hline Komisyon modeli yaklaşımı & $\begin{array}{l}\text { veriler tümevarım analizi ve içerik analizi teknikleri kullanılarak çözümlenmiştir. Bu } \\
\text { araştırmadan elde edilen bulgular, komisyon model yaklaşımının gerçek yaşamda }\end{array}$ \\
\hline Ĕgitimde yaratıcı drama & var olan problem durumlarını çözen, sorumluluk üreten ve sosyal etkileşim yolu ile \\
\hline Öğretmen adaylart & $\begin{array}{l}\text { işbirlikli öğrenme ortamı sunan bir yaklaşım olduğunu göstermistir. Bu bulgulardan } \\
\text { hareketle. Komisyon model uvgulamalarının drama disiplini icerisinde daha fazla ver }\end{array}$ \\
\hline Okul-gerçek yaşam ilişkisi & bulması ve okul gerçek yaşam ilişkilerinin bu anlayışla yapılandırılması önerilmiştir. \\
\hline \multicolumn{2}{|l|}{ Dorothy Heathcote } \\
\hline \multicolumn{2}{|c|}{$\begin{array}{l}\text { A New Drama Approach Questioning The Relationship Between } \\
\text { School-Real Life and Taking Responsibility : Commission Model }\end{array}$} \\
\hline Article Info & Abstract \\
\hline DOI: $10.21612 /$ yader.2018.012 & $\begin{array}{l}\text { This study was carried out to define Dorothy Heathcote's "Commission Model" } \\
\text { approach, which is one of Dorothy Heathcote's most recent drama approaches and }\end{array}$ \\
\hline Article History & $\begin{array}{l}\text { which is not well known in the field of drama. From this definition, the aim of this } \\
\text { research is to develop an application example and analyze the experiences of the students }\end{array}$ \\
\hline 07.05 .2018 & included in the application example in line with the purpose of the commission model. \\
\hline 15.06.2018 & $\begin{array}{l}\text { The research is structured by action research from one of the qualitative research } \\
\text { designs. The research group was composed of teacher candidates from different } \\
\text { departments of Ankara University Faculty of Educational Sciences in the period of } \\
2015-2016 \text {. Fourteen female and eight male teacher candidates were included in the }\end{array}$ \\
\hline Keywords & $\begin{array}{l}\text { study group. During the implementation process, the data were collected by the way of } \\
\text { observations, interviews, visual presentations, reflective summaries, voice recording }\end{array}$ \\
\hline Commission model approach & and video. The data collected during the research process were analyzed by inductive \\
\hline Drama in education & $\begin{array}{l}\text { analysis and content analysis techniques. The findings obtained from this research } \\
\text { reveal that are the commission model is an approach that solves problem situations }\end{array}$ \\
\hline Teacher candidates & in real life, produces responsibility and presents a collaborative learning environment \\
\hline School-real life Relations & through social interaction. Based on these findings; it is proposed that the commission \\
\hline Dorothy Heathcote & $\begin{array}{l}\text { model applications must find more space in the drama discipline and that school-real } \\
\text { life relations have to be structured with this understanding. }\end{array}$ \\
\hline
\end{tabular}

\footnotetext{
* $\quad$ Bu makale Zeki Özen tarafından hazırlanan "Drama Yaklaşımlarından Komisyon Modelin Öğretmen Adaylarına Okul-Gerçek Yaşam İlişkisi Kurma Becerilerini Kazandırmada Kullanımı” başlıklı doktora tez çalışmasından üretilmiştir.

1 Dr., Ankara Üniversitesi Eğitim Bilimleri Fakültesi, E-posta: ozenzeki@hotmail.com

2 Prof. Dr., Ankara Üniversitesi Eğitim Bilimleri Fakültesi, E-posta: omeradiguzel@gmail.com
} 


\section{Giriş}

Eğitim çalışmalarında doğal ortamlar oluşturma çabası sürekli tartışılan konulardan biri olmuştur. Eğitim sistemlerinde bu doğallığa ulaşmak adına farklı yollar denenmiş olsa da tartışmalar güncelliğini korumaya devam etmektedir. Bu bağlamda genel olarak “doğallık” kavramı, bireylerin gelişim dönemi özelliklerine göre tanımlanmıştır. Eğitim bilimleri geleneklerinde Rousseau, Dewey gibi filozoflar bu kavram üzerinde durmuş, eğitim ve doğallık ilişkisini “doğa” kavramı ile birlikte irdelemişlerdir.

Doğa ve çevre kavramlarının işlevsel bir öğretim aracı olabilmesi için belirli planlamalar doğrultusunda eğitim alanı ile buluşturulması gerekmektedir. Doğa ve çevreyi araç olarak kullandığımız eğitim süreçleri, dolaylı öğrenmeleri içermektedir. Daha nitelikli öğrenme süreçlerini edinmek için çevre ve doğa ortamlarını belirli amaçlar doğrultusunda donatmak gerekmektedir. Doğa ve çevrenin bir parçası olan "sosyal çevre" bu donanımın değerli bir parçası olarak düşünülebilir. Dewey (1996)'e göre sosyal çevre, bireyin duygusal ve düşünsel tutum ve davranışlarını, belli dürtüler, belli amaç ve sonuçlara ulaştıracak eylemlere kanalize ederek biçimlendirir.

Bireyin sosyal çevresi ile gerçekleştirmiş olduğu etkileşim birçok eğitim yaklaşımında ya da yönteminde önemli bir araç olarak görülmektedir. Bireylerin sosyal çevrelerini ve bu çevrede öğrendiklerini önemseyen yöntemlerden birisi yaratıcı dramadır. Drama çalışmaları, grup etkileşimine dayalı ve grup üyelerinin yaşam deneyimlerinden beslenen süreçleri içermektedir. Drama çalışmalarına katılan grup üyeleri, belirli dramatik durumlara yönelik canlandırmalar gerçekleştirerek düşüncelerini ortaya koyarlar. Sürece dahil olan bireyler, oluşturmuş oldukları sosyal etkileşimleri sağlıklı bir biçimde devam ettirmek adına kimi roller üstlenirler. Drama çalışmalarında bireyler genel olarak canlandırmaların oluşum süreçlerinde; hem kendi düşüncelerini doğru aktarmak hem de grubunda bulunan diğer bireylerin düşüncelerini doğru algılamak için uğraş verirler.

Drama uygulamalarında, işlenen konuya ilişkin üstlenilen rol çalışmalarından önce; zihinsel ve fiziksel hazırlık çalışmaları gerçekleştirilmektedir. Bu hazırlık aşamaları sırasında bireyler, yaşam deneyimlerinin zenginliği sınırında diğer katılımcılarla iletişime geçmektedirler. Bireyler; sahip olduğu deneyim zenginliklerini diğer katılımcılarla paylaşmak için kendilerini rahat ve yargısız ifade edecekleri doğal ortamlara gereksinim duymaktadırlar. Deneyim zenginliği farklı olan bireylerin, işlenen temaya ilişkin görüşlerini bildirmeleri ve paylaşıma geçtikleri diğer bireylerde var olan farklı birikim seviyelerine, sosyal etkileşim yoluyla somut bir biçimde tanık olmaları, yapılan işin "kurgusal” olduğu gerçeğini beslemektedir.

Deneyim zenginliğini kurgusal bir ortamda paylaşan bireyler, kısa bir ön hazırlık ile yaptıkları canlandırmalara inanma konusunda sorunlar yaşamaktadır. -Mış gibi yapma sürecine inanmayan bireylerin dilsel, fiziksel, mekânsal, ruhsal, duygusal, vb. açılardan rol gerekliliklerini yerine getirmedikleri görülmektedir. Rolün gerekliliğini yerine getiremeyen bireylerin "-mış gibi yapamama" durumlarının ise kurgusal ortamlardaki "inanmayışı” daha da beslediği görülmektedir. Bu gerekçeyle bireylerin role olan inanıştan daha da uzaklaştı̆̆ söylenebilir.

Estetik kaygılar, izleniyor olma durumu, canlandırılan role kültürel ve düşünsel açıdan uzak olma durumu, canlandırma yapmaya yönelik deneyim eksikliği, canlandırmalarda kendin gibi olamama durumu, heyecan, mekân, zaman, vb. gibi gerekçelerle canlandırmalarda üstlenilen rollere inanma durumu azalabilmektedir. Üstlenilen rollere yönelik gerçekleştirilen fiziksel ve zihinsel 
hazırlıkların da yetmediği durumlarda katılımcı, oynarken inanmadığı rolleri canlandırabilmektedir. Rolüne inanmayan katılımc1, rolün gerektirdiği tutumu sergileme, rolü devam ettirme gibi başlıklarda sorunlar yaşamaktadır.

Role inanış kavramı bir çok drama öncüsü tarafından önemsenmiştir. Drama alanında çalışan öncüler, kendi özgün yaklaşımlarında üstlenilen role inanışı arttırmak için deneysel çalışmalarda bulunmuş ya da farklı teknikler kullanma yoluna gitmişlerdir. Bu doğrultuda sıklıkla psikoloji alanı çalışmalarına odaklanan öncüler, doğal olarak tiyatro çalışmalarındaki yaklaşımları da gözden geçirmiş ve her iki alandan "role inanışı" destekleyecek bağlantılar bulmaya çalışmışlardır.

Sözgelimi dramanın alan öncülerinden olan Bolton’a göre, bir diğer alan öncüsü olan Brian Way (akt. Metinnam, 2016) Stanislavski'den etkilenmiştir. Öğrencilerin gelişmesine yardımc1 olabilmek için özellikle duyarlılık, yoğunlaşma ve sezgi konusunda, üçünü birbirine koşut tuttuğu drama süreçleri tasarlamıştır. Bu örneğin yanı sıra bir diğer öncü olan Dorothy Heathcote, drama oturum planlamalarını tasarlarken etkilendiği kişilere örnek olarak Bruner'i işaret etmiştir. Heathcote (Heathcote, 2010 akt. Özen, 2011)'a göre; "Drama sosyal bir sanattır - amaca odaklanmış etkileşim içerir. Bir öğretmenin sınıflarda fikir birliği elde etmeleri için çeşitli yollarla yardımcı olması gerekmektedir."

Bruner, bu yardım yolları için üç aşama belirtmektedir:

- İkonik (resimsel, görüntüler)

- Sembolik (konuşma, tarif etme, yazma) ve

- İfadeye yönelik (“-mış gibi” davranışını gerçek bir şekilde hareketle göstererek oynamak)

Drama dersinin planlamasına ilişkin Bruner'in çalışmalarını önemseyen Dorothy Heathcote; gerçek, kurgu, katılımcı rolü, -mış gibi yapma gibi başlıkları Brian Way ve Peter Slade gibi kişinin kendi duygu ve kaynaklarını oyun yaratımı sürecine aktaran Stanislavski anlayışıla değil, kişinin keşiflerini ve sonradan ortaya çıkan gösterme durumlarını öğrenme sürecine aktaran Brechtyen bir anlayışla yapılandırmaktadır (Fiala, 1977; Hesten, 1993; Eriksson, 2009).

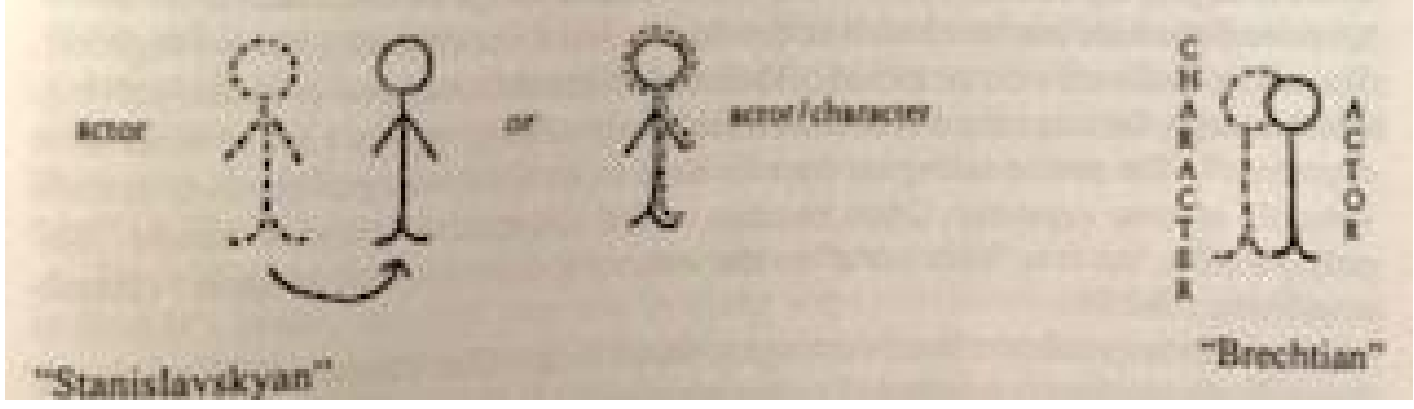

Şekil 1. Dorothy Heathcote'un etkilendiği rol anlayışı. (Fiala 1980'den akt. Erriksson, S.)

Birçok drama sınıfında drama eğitmeninin temel ilgilendiği şey; gerçek yaşam durumlarının simülasyonu sayılabilecek gerçek illüzyonlar yaratmaya çalışmaktır. Böylesine bir gelenekle yapılanan drama anlayışlarında pedagojik amaç; ya canlandırma yapan kişinin bilinçli bir psikolojik adım atarak karakterin ruhunun içine girmesidir (üst-sol çizim) ya da kendi kişiliği ile karakteri birleştirip tamamen kaynaşık bir karakter yaratmasıdır (üst-orta çizim). Heathcote’un yaklaşımlarında 
ise genel düşünce "başkası" gibi olduğuna inanmak ya da "başkası" gibi yapmak değildir. Temel amaç, kendine ait bilincini korurken bir başka kişinin inandırıcı, karakteristik tutumunu üstlenmeye çalışmaktır (üst-sağ çizim) (Eriksson, 2009).

Birçok drama yaklaşımında tartışılmak istenen temaya ilişkin derinlikli düşünce paylaşımı yeterince gerçekleştirilememektedir. Toplum için itici bir güç olabilecek drama disiplini, gerçekleştirilen rol oynamaların yüzeysel bir biçimde yapılmasından dolayı olası gücünü sınırlı bir biçimde kullanabilmektedir. Bu gerekçeden hareketle drama alan öncüleri, drama disiplininin işlevini yerine getirebilmesi ve gücünü kullanabilmesi adına yeni yaklaşımlar geliştirmişlerdir.

Dorothy Heathcote, kendi özgün yaklaşımlarında kurgu ve gerçek kavramlarını özenle işlemektedir. Farklı yaşam deneyimlerine sahip katılımcıların sosyal etkileşimini önemseyen Heathcote, katılımcılar tarafından gerçekleştirilmesi kolay sayılabilecek olan görevler ile çalışmalarına başlamaktadır. Heathcote, katılımcılarının kendilerini başarısız hissetmeyecekleri durumlar oluşturarak, onlarda özgüven yaratmaya çalışır.

Bruner'in sosyal öğrenme aşamaları ile yapılanan Dorothy Heathcote'un özgün yaklaşımlarının gereksinimler ve gelişmeler doğrultusunda belirli bir evrimsel süreç geçirdiği görülmektedir. Heathcote'un ilk zaman drama çalışmalarında çatışma kavramının odakta olduğu, insanlığa ilişkin karmaşa sayılabilecek durumlar işlenmiştir. Heathcote (1985), kendi hakkında yazılmış yazıların toplandığı kitapta; kendi yaklaşımlarının dramaturjik odağında 1980'li yıllara varıncaya değin "gerilim” kavramının yer aldığını belirtmektedir. Bu biçimdeki bir drama anlayışını ise şu biçimde tanımlamaktadır: "Drama; insanların karşı karşıya kaldıkları zorlu durumlarla mücadele etmekten dolayı, insanları değiştirebilen durumlardır.'

Dorothy Heathcote'un ilk zaman sınıf uygulamalarında görülen kurmacaların sınıf öğrencileri ile beraber, işbirliği içerisinde yapılandığı görülmektedir. İşbirliği içerisinde yapılanan tüm kurmacalarda belirli anlaşmalar göze çarpmaktadır. Belirli bir inanış oluşturmak adına öğrenciler ve Heathcote'un birlikte verdiği kararlar "Her öykünün öncesinde bir başka öykü vardır." anlayışını kabul etmektedir.

Heathcote; Kanadalı sosyolog Erving Goffman'ın tiyatro metaforlarından ödünç alarak kullandığ 1 "rol" ve "performans" gibi terimlerin bir çok farklı toplumsal bağlama aktarıldığını ifade etmektedir. Heathcote aynı anlayıştan hareketle ilk drama örneklerinde Goffman'ın "çerçeve" anlayışını kullanarak rol işlevlerini anlatan bir çerçeve sunmuştur.

Heathcote, 1989 yılında da Ulusal Drama Eğitimi Derneği tarafından gerçekleştirilen uluslararası katılımlı bir konferansta sunduğu "Drama için mücadele - Eğitim için mücadele" başlıklı konuşmasında Erving Goffman'dan etkilenerek oluşturduğunu ifade ettiği "çerçeve uzaklık" kavramına ilişkin bilgi aktarımında bulunmuştur (Eriksson, 2009).

Aslında Goffman, sosyal dünyamızın tüm yönlerini kapsayacak teorik bir yaklaşım geliştirmemis, ancak iki veya daha fazla insanın birbirlerinin fiziksel varlığından oluşan ortamlar olarak sosyal durumlar-etkileşim düzeni diye tanımladığı bağlamlara dair kapsamlı bir analiz geliştirmiştir. Bu bağlamlar diğerleriyle yüz yüze aktivitelerden oluşan, günlük sosyal durumlar, kurumsallaşmıs, yapılar (okul, iş yeri) ya da olağan dışı sosyal olayları da (düğün, kaza) kapsayacak denli genis, ve insan hayatını domine edecek kadar çeşitlidir (akt. Bayad, 2016). 
Dorothy Heathcote’un gerçek yaşam odaklı drama anlayışı, belirli bir süre sonra dönüm noktası sayılabilecek bir kararla "karmaşa içindeki insan” yaklaşımından "uzman mantosu” yaklaşımına doğru evrilmektedir. Uzman mantosu çalışmaları teorik ve bilimsel araştırmaları, performans çalışmaları ile buluşturan bir yaklaşım olarak değerlendirilebilir. Bütün sınıf öğrencilerinin işbirliği içerisinde uzmanlar, arkeologlar, mimarlar vb. roller üstlendikleri rol oynamalar olarak tanımlanmaktadır. Psikolojik açıdan bakıldığında öğrencilerin karakterlere bürünmedikleri ama üstlenilen uzmanlığın gerektirdiği ortak sorumluluk ve değerleri benimseyerek oluşturdukları rollerdir (Tor, 2008).

Heathcote yöntembiliminin toplumsal işlevi; tutumların sınanması, gerektiğinde değiştirilmesi ve öğrencilerin kişisel beklentilerinin artmasına odaklanmaktadır. Çalışmaların başlangıcında öğrenciler sembolik düşünebilmeleri için teşvik edilirler. Buna bağlı olarak öğrencilerin yaratıcılıkları sembolik grup etkinliklerine yönelerek grup içerisinde bir sorumluluk oluşmasını sağlamaktadır. Drama dersi, öğrencinin sorumluluk alma konusunda bir karar mekanizması oluşturması ve geliştirmesi bağlamında yapılanmış olur (Hesten, 1993).

Dorothy Heathcote'un özgün yaklaşımları zamandizinsel bir biçimde incelendiğinde, gerçek yaşamda dönüştürücü olma iddiasının her yaklaşımda korunduğu görünmektedir. Heathcote’un özgün yaklaşımlarından sonuncusu olan komisyon model uygulamaları ise bu iddiayı gerçekleştirmek için kurgusal ortamlardan uzaklaşarak gerçek yaşam ortamlarını kendisine mekân edinmiştir. Drama dünyası için çok cesur sayılabilecek bu adım, katılımcılarına daha gerçekçi sorumluluklar üretme için firsatlar yaratmaya çalışmaktadır.

Uzman mantosu çalışmalarında katılımcılar olabildiğince gerçek tepkiler verseler de yapılan iş ve üstlenilen görevler belirli bir kurguya dahil bir biçimde ilerlemektedir. Katılımcının vermiş olduğu doğal ve gerçekçi tepkiler; mekân kurgusu, katılımcı tepkisi, sosyal etkileşimin sınırlı olması, üstlenilen role olan uzaklık gibi başlıklarla bir biçimde bozguna uğramaktadır. Doğal ve gerçekçi sorumluluklar üretilen ama kurgu olduğu bilinen uzman mantosu yaklaşımını gerçek yaşama taşıyan komisyon uygulamaları ise her şeyiyle gerçek olan bir ortam yaratmaya çalışmaktadır.

Heathcote, dramanın özünde yer alan kurgu ve gerçek ayrımının bozguna uğradığı komisyon çalışmalarına ilişkin şu ifadeleri kullanmaktadır :

"Uzman Mantosu ve Rolün Yuvarlanması çalışmaları, öğrencilere olgun birer insan olarak kendi kapasitelerini sınama ve kuşkusuz kendi ilgi ve becerilerini gösterme olanağ 1 verir. Komisyon Modeli ise dünya işleri ve beraber öğrenmede aktif katılım diyebileceğimiz iki noktada kusursuz bir bağlantı oluşturur." (Heathcote, 2000)

Komisyon model uygulamalarının gerçek yaşamda gerçekleşiyor oluşu drama alanında kabul edilmiş bir kural olan "kurgusal canlandırmalar" başlığı ile çelişmektedir. Bu gerekçe nedeniyle komisyon model uygulamalarına drama alanında şüphe ile yaklaşılmaktadır. Araştırma kapsamında yapılan etkinlikler ile yukarıda sözü geçen şüpheye yanıt aranmaktadır. Bütün bu gerekçeler araştırmanın problem durumunu oluşturmaktadır.

\section{Araştırmanın Amacı}

$\mathrm{Bu}$ araştırmanın amacı drama alanı öncülerinden Dorothy Heathcote'un drama yaklaşımlarından olan "komisyon model" yaklaşımının odakta olduğu bir uygulama örneği geliştirmek ve uygulama örneğine dahil olan öğrencilerin yaşantılarını komisyon model amaçları doğrultusunda analiz etmektir. 


\section{Araştırmanın Önemi}

$\mathrm{Bu}$ çalışma; gerçek yaşamda oluşan etki-tepki alıverişlerinin kurgusal ortamlarda deneyimleyen, alışılagelmiş drama yaklaşımlarından farklı olarak gerçek yaşamda kurgulanmış dramatik durumları içermektedir. Komisyon model uygulamalarının temel felsefesi; eğitim ve eğitimde drama çalışmalarını gerçek yaşamla buluşturmaktır. Bu yönüyle "komisyon model" drama dünyası için yeni bir yaklaşım olarak görülmektedir. Bir çok drama alan uzmanının henüz yeterince tanımadığı "komisyon model" yaklaşımının ayrıntılarını belirlemek ve uygulama örneği ile beraber komisyon model yaklaşımını ortaya koymak drama alanı açısından önem taşımaktadır. Bu bağlamda araştırma; dünyada bu başlıkta gerçekleştirilen sayılı çalışmalardan biri olması açısından önemlidir.

\section{Yöntem}

\section{Araştırma Modeli}

$\mathrm{Bu}$ çalışma, nitel araştırma desenlerinden eylem araştırması deseniyle yapılandırılmıştır. Eylem araştırması, bir okulda çalışan yönetici, öğretmen, eğitim uzmanı veya diğer tür kuruluşlarda çalışan mühendis, yönetici, planlamacı, insan kaynakları uzmanı gibi bizzat uygulamanın içinde olan bir uygulayıcının doğrudan kendisinin ya da bir araştırmacı ile birlikte gerçekleştirdiği ve uygulama sürecine ilişkin sorunların ortaya çıkarılmasını ya da halihazırda ortaya çıkmış bir sorunu anlama ve çözmeye yönelik sistematik veri toplamayı ve analiz etmeyi içeren bir araştırma yaklaşımıdır (Yıldırım, \& Şimşek, 2013).

Eylem araştırması, problem çözmeye yönelik ve süreklilik gösteren bir süreçtir. Bu Schön'ün (1983) tanımladığı "yansıtıcı düşünme” ile benzerlik gösterir. Yansıtıcı düşünmeyi bir sorgulama süreci olarak tanımlayan Schön, bu sürecin bir problem durumuyla başladığını, belirli değişiklikler yoluyla bu problemin çözüldüğünü ve bu aşamada üzerinde düşünülecek yeni problemlerin belirlendiğini belirtmektedir. Benzer şekilde eylem araştırması süreci; problem belirleme, veri toplama, veri analizi, eylem planı belirleme, eylemi gerçekleştirme ve alternatif ya da yeni bir eyleme karar verme aşamalarından oluşmaktadır (akt: Yıldırım, \& Şimşek, 2013).

\section{Çalışma Grubu}

Çalışmanın araştırma grubunu, Ankara Üniversitesi Eğitim Bilimleri Fakültesi'nde 20152016 eğitim öğretim döneminde farklı anabilim dallarında öğrenim görmekte olan öğretmen adayları oluşturmaktadır. Çalışma grubunda yer alan öğretmen adayları aynı zamanda kısa adı EYAT olan Eğitimde Yaratıcı Drama Topluluğunun gönüllü katılımcılarıdır. Çalışma grubunda on dört kadın, sekiz erkek öğretmen adayı bulunmaktadır. Çalışma evreninin oluşturulmasında amaçlı örnekleme yöntemlerinden uygun durum örneklemesi tercih edilmiştir. Uygun durum örneklemesi, deney grubunun kolay ulaşılabilir olmasıyla ilişkilidir (Ekiz, 2009). 


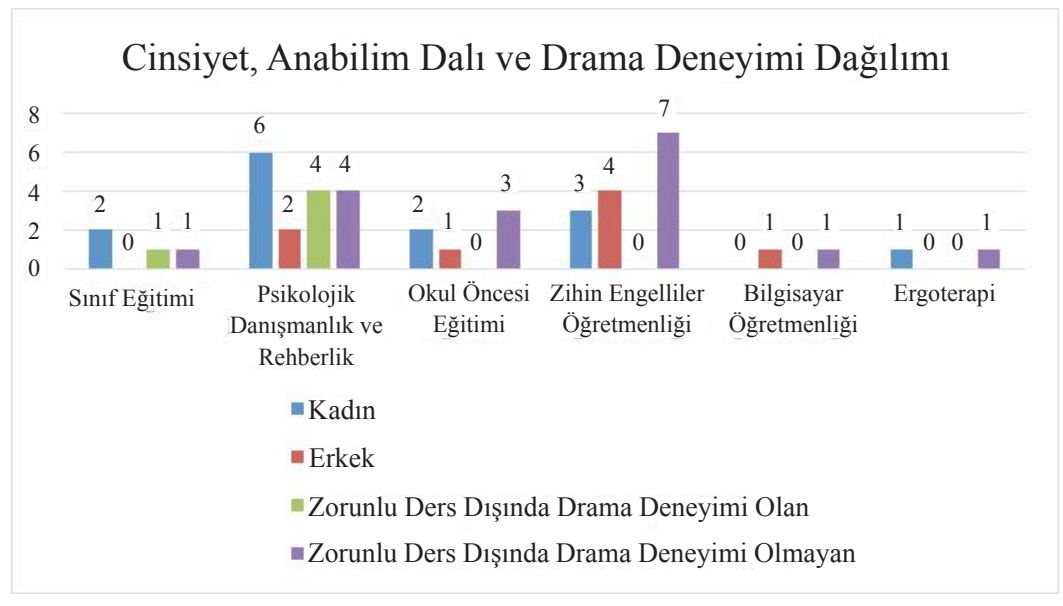

Grafik 1. Cinsiyet, Anabilim Dalı ve Drama Deneyimi Dağılımı

\section{Veri Toplama Kaynakları, Araçları ve Yöntemleri}

Eylem araştırmasında sistematik veri toplama süreci gerçekleştirildiğinden, araştırmaya başlamadan önce ne tür verilerin, nasıl ve ne sıklıkta toplanacağına karar verilir (Kuzu, 2005). Toplanan verilerin niteliğini arttırmak amacıyla çeşitli veri kaynaklarından veri toplanmıştır. Araştırmanın asıl çalışma grubu olan öğrenci grubunun yanı sıra öğrenci grubunun temas ettiği diğer paydaşlardan toplanan veriler de çalışmaya yön vermiştir. Bu doğrultuda araştırma grubu öğrencileri, yaşadıkları süreci yansıtan raporlar oluşturmuştur. Süreç sonunda araştırma grubu ile odak grup görüşmesi gerçekleştirilerek veriler çeşitlendirilmiştir.

\section{Verilerin Toplanması}

Çalışma grubunun araştırma süreci içindeki yaşantıları, gerçek yaşam içerisinde yer alan bir yapılanmayı sahiplenmeleri, bu sahiplenmenin kırıldığı noktalar ve gerekçeleri, kendi grupları içerisinde yaşadıkları öznel durumlar ve hissettirdikleri, araştırma grubunu motive eden ve güdüleyen etmenler gibi durumlar irdelenmeye çalışılmıştır. Bu başlıkların yanı sıra öğrenci topluluğunun araştırma süreci içerisindeki kendi yaşantılarından yola çıkarak, "komisyon model" yaklaşımını tanımlamaları istenmiştir. Son olarak katılımcılardan çalışma içerisinde yer alan gerçek ve kurgusal durumların sorumluluk üretme noktalarında nasıl, ne biçimde etkili olduğuna ilişkin değerlendirme yapmaları istenmiştir. Tüm çalışmalar bittikten sonra araştırma grubu tarafindan çalışma istemcisi olan Ankara Üniversitesi Sağlık, Kültür ve Spor Daire Başkanlığı’na genel bir rapor hazırlanmıştır. $\mathrm{Bu}$ rapor çalışmanın diğer paydaşlarından toplanan istekleri de doğrudan içermektedir.

Raporlar teslim edildikten sonra yaşanan süreci daha ayrıntılı betimlemek ve araştırma grubunun dinamiklerini ortaya koymak amaciyla odak grup görüşmeleri gerçekleştirilmiştir. Farklı zamanlarda gerçekleşen üç “odak grup görüşmesi” katılımcıları olabildiğince farklı alt çalışma gruplarından seçilmiştir.

\section{Verilerin Analizi}

Elde edilen nitel verilerin analizi için metinlerden yola çıkarak kodlamalar yapılmıştır. Kodlama süreci metin veya görsel verileri küçük bilgi kategorileri içine toplamayı, bir çalışmada kullanılan farklı veri tabanlarından gelen kod için kanıt aramayı ve sonra koda bir etiket vermeyi 
içermektedir (Creswell, 2013). Araştırmacı tarafından verilen kodların yanına alınan anımsatıcı notlar kategorileri belirlemede yardımcı olmuştur. Oluşan kategorilerde kesişen ortak noktalar belirlenerek temalar oluşturulmuş ve oluşturulan temalar yorumlanmıştır.

\section{Bulgular}

\section{Uzman Mantosu Yaklaşımı ile Kültür Sanat Merkezi Oluşturuyoruz}

Araştırmanın bu aşamasında öncelikle araştırma grubu üyelerinin uzman mantosu uygulamalarına yönelik düşünceleri ve yaşantıları kendi ifadeleri üzerinden değerlendirilmiştir. Grup üyelerinin ifadeleri analiz edildiğinde özellikle kazanımlar, kendi motivasyonlarını düşüren etmenler, komisyon modele hazırlık süreci, rol ve gerçeklik ilişkisi, gerçekleştirilen ön hazırlıklar başlıkları üzerinden temalar oluşturulmuştur. Grup üyelerinin ifade etmiş olduğu deneyimlerden elde edilen verilerin birbirileri ile ilişkisini ortaya koyan bir harita oluşturulmuştur. Oluşturulan bu harita ile katılımcıların çalışmaya yönelik düşünce ve yaşantıları görselleştirilmiştir.

Alan çalışmalarına geçilmeden önce gerçekleştirilen uzman mantosu çalışmalarının, araştırma grubu üyelerini olumlu bir biçimde etkilediği gözlemlenmiştir. Uygulama sırasında araştırma grubu üyeleri, bir kültür sanat merkezinde yer alabilecek tüm ayrıntılara ilişkin derinlikli düşünceler üretmiş ve araştırmışlardır. Bu nedenle kurgusal bir ortamda yapılandırılan uzman mantosu uygulamalarının katılımcıların bilgi evrenine ve yaşam deneyimi paylaşımına katkı sağladığına inanılmaktadır. Uzman mantosu sürecinde araştırmacı grubun bilgiye ulaşması amacıyla işbirlikli çalışmalar yürütmesi için uygun bir motivasyon ortamı yaratılmaya çalışılmıştır. Bu nedenle araştırma grubu üyelerinin uzman mantosu uygulamasına yönelik düşünceleri ayrı bir biçimde ele alınmıştır. Araştırma grubunun uzman mantosu uygulamasına yönelik değerlendirmeleri şu biçimde haritalandırılmıştır:

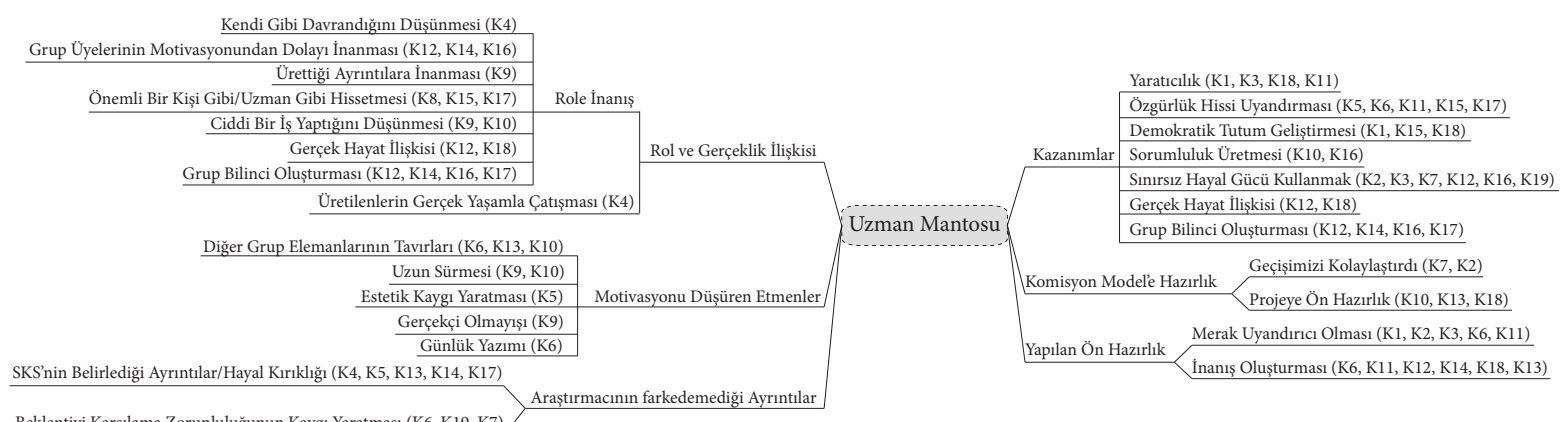

Şekil 2. Araştırma Grubu Üyelerinin Uzman Mantosu Uygulamasına Yönelik Düşünceleri

\section{Alan Çalışmaları Başlıyor: Komisyon Model Uygulamasına Yönelik Görüşler}

Uzman mantosu çalışmalarının ardından komisyon model uygulamasının diğer etkinliklerinin uygulanması aşamasına geçilmiştir. Katılımcıların alan çalışmalarına yönelik betimlediği cümleler kategorileştirilmiş ardından da üst temalara ulaşılmıştır. Belirlenen üst temalarda yer alan ifade sıklıkları katılımcıların söylemlerine göre haritalandırılmıştır

Komisyon model uygulamalarının temel anlayışında yer alan; gerçek insanlarla temas ve gerçek dramatik durumlarla baş etme durumu, grup üyelerinin ayrıntılı düşünmelerini sağlamıştır. Uzmanlar tarafindan ifade edilen ayrıntılar ve alanda temas edilen insanların beklentileri yeni 
öğrenme başl1kları oluşturmuştur. Böylece araştırma grubu üyelerinin daha önceden düşünmediği ayrıntılar yaşam deneyimi ve paylaşımı yolu ile bir sonraki uygulama adımına aktarılmıştır.

Alan çalışmalarında iletişime geçilen insanların aktarımları, araştırma grubu üyelerinin Kültür Sanat Merkezi bölümlerine ilişkin ufuklarını geliştirmiştir. Araştırmanın yöntemi olan eylem araştırması yönteminin anlayışında olduğu üzere grup üyeleri alan çalışmalarının bir sonraki adımını alandan elde ettikleri veriler üzerinden yapılandırmışlardır. Grup üyelerinden bazılarının alanda gerçekleştirilen etkileşimlerle ilgili olarak belirttiği ifadelerden bazıları şu biçimdedir:

K1: Her toplantıda bir sonraki adımımızı belirleyerek planımızı yapıyorduk. Gruplara ayrilarak Ankara'daki Kültür merkezlerini gezdik. Gezdiğimiz yerlerde çektiğimiz video ve fotoğrafları topluluğa sunduk. Bilgi paylaşımlarında bulunduk. Olumlu-olumsuz yönlerini konuştuk. Neleri elimizde tutmalıydık. Duvarda asılı duran küçük bir çerçeve bile bizim için önemliydi. Kaldı ki ışıklandırma, duvar rengi, parkeler... Artık her şeyi daha ayrıntılı düşünüyorduk ve elimizde somut bir mekanımız vardı. Şunun da önemli olduğunu düşünerek vurgulamak istiyorum; uzman mantosunda yaptığımız çalışmaları her zaman cebimizde tuttuk.

K11: Kültür evinin yapılandırılmasında ilk adım olarak Ankara'daki Kültür Sanat Merkezlerinin gezip bilgi toplanması bu bilgiler doğrultusunda fikirlerimizi geliştirmeyi planladık. İlk olarak gidilen yer Mamak Kültür Merkezine gidildi. Sonra Bambu Kültür Evine sonrada Kore Kültür Merkezine gidildi. Bunların arasından benim en sevdiğim Kore Kültür Merkezi oldu çünkü modern bir görünüme sahipti ve ilgi çekiyordu. Buralara giden arkadaşlarımız fotoğraflarla videolarla sunum yaptılar ve hep beraber bu yerlerin artıları eksileri üzerine konuştuk.

Araştırma grubu üyelerinin farklı alan çalışmalarına yönelik olarak belirtmiş oldukları bu deneyim ifadeleri, var olan düşüncelerinin başka deneyimlerden olumlu bir biçimde etkilendiğini göstermektedir. Alan çalışmaları sırasında oluşan bu etkileşimler, ayrıntı düşünmenin yanı sıra üyeler için öğretici ortamlar da yaratmıştır. Araştırma grubunun etkileşimli temaslar yolu ile öğrendiklerine ilişkin görüşlerinden bazıları şöyle örneklendirilebilir:

K1: Ayrıca her gittiğimiz yerden farklı bir şey öğrendik. Salonlarının adlandırılmasını, kursların zamanlarını nasıl ayarladıklarını öğrendik. Aslında daha önce Cermodern dışında bir yere gitmemiştim. Kültür merkezleri konusunda çok bilgili değildim. Bu çalışmalarla birlikte birçok şey öğrendim. İlgim arttı. Farkındalık kazandım. İlk başladığımızda kültür evi deyince aklıma pek bir şey gelmiyordu. Hatta hepimiz arama motoruna yazıp bir bakmıştık. Şu anki noktamıza baktığımızda orada yazanların ne kadar sınırlı olduğunu görüyorum. Bir kültür merkezi orada yazanlardan ibaret değilmiş. Çok kapsamlı, ayrıntılı çalışmalar gerektiriyormuş.

K9: Ankara' daki kültür evleri nası1, neler yapıyorlar görmek adına yaptığımız kültür evi ziyareti deneyimimden bahsetmek istiyorum. Kültür evinin sahibi çok ilgiliydi. Sorularımı dikkatle dinledi. Özenle cevaplar verdi. Bambu kültür Evi dediğimiz yer eski bir apartmanın son katında odaları bölümlere ayrılmış bir yer. Ama içinde inanılmaz güzel etkinlikler gerçekleşiyor. Kültürevi sahibine, üç katlı birçok odası olan bir binadan bahsedince hayretler içerisinde kaldı. Neler neler yapardım orda dedi. Haklıydı çünkü kendisi yaklaşık beş odası ve küçük bir terası olan katta çok güzel etkinlikler gerçekleştiriyordu. Öğrendik ki binamızın eski olması o kadar da kötü bir durum değildi. 
K14: Oradaki sorumlu kişiyle yarım saate yakın bir röportaj yaptık. Bu röportaj çok faydalı oldu. Bu kültür merkezinde insanların neleri sevip sevmediği açık olarak söyledi. Salona gittiğimiz zamanda diğer arkadaşlar da farklı kültür sanat evleriyle ilgili topladıkları bilgileri bizlerle paylaştılar. Bu paylaşımlar çok faydalı oldu. Çünkü birçok kültür merkezine ilişkin fikir sahibi olmuştuk.

Araştırma grubu üyeleri, alan çalışmalarında yaşamış oldukları bu deneyim paylaşımlarından edindikleri bilgiler aracılığı ile yeni bir bilgi evrenine ulaşmışlardır. Grup üyelerinin paylaşmış olduğu alan deneyimleri ve birbirlerine yapmış oldukları sunumlar, öğrenme düzeylerine yeni bir boyut kazandırmıştır. Doğrudan alan çalışmaları ile gerçekleşen bu öğrenmelerin, araştırmanın diğer aşamalarında yapılan etkinliklerin niteliğini belirlediği görülmektedir. Sözgelimi bir kültür sanat merkezinin sorumlusu ile görüşmelerde bulunmak, grup üyelerine daha önceden düşünmedikleri ayrıntılara ilişkin bir görgü kazandırmıştır. Yeni yaratımlarını bu öğrenmelerden yararlanarak devam ettiren grup üyeleri, alanda karşılaştıkları ve soru yönelttikleri bireylerden yeni bilgiler edindikleri durumlar da yaşamışlardır. Sözü edilen bu etkileşimli bilgi edinme süreci, komisyon model uygulamasının tüm alan çalışmalarında gözlemlenmiştir. Bu bağlamda araştırma grubu üyeleri yeni öğrenmelerden edindikleri deneyimleri bir sonraki çalışmaya aktarıp yine alan çalışmalarına çıkmışlardır. Var olan veri toplama araçlarını gözden geçirip, düzenlenmiş yeni veri toplama aracı ile alana çıkmanın kendilerine katkı sağladığını ifade etmişlerdir.

K5: Saha çalışmalarından sonra yaptıklarımızı gözden geçirdik hatta biz fotoğraf atölyesini baştan yarattık. Bu konuda da hiçbir şey bilmediğim bir kez daha anladım.

K9: Saha çalışmasının en güzel yanlarından biri insanlarla temas etmekti. Dönüt almamız almamamız değildi problem. Bazen alamamak da başka bir çıktıya götürüyordu.

K11: Alana çıkıp önce neler düşündügüumüzü anlattık ardından sorularla öğrencilerden veri topladık.İlk alana çıkışımızda biraz acemi kaldığımızı söyleyebilirim. Sorularımızın kısıtlı ve onay almak istercesine olduğunu daha sonra fark ettik. Alana çıkıp veri toplamak bence çok değerli çünkü farklı deneyimler, fikirler, bakış açıları eksikliklerimizi görmemizi ve geliştirmemizi sağlıyor.

Araştırma grubu üyelerinin yukarıda yer alan ifadelerinden hareketle, alan çalışmalarının esnek ve değişken bir yapıda olduğu görülmektedir. Komisyon model uygulaması anlayışında odakta olan gerçek insanlarla temas ve deneyim paylaşımlarının grup üyelerinin öğrenme sürecini olumlu bir biçimde etkilediği gözlemlenmiştir.

Araştırma grubu üyelerinin komisyon model uygulamalarında yaşadıkları süreçlere yönelik ifadeleri incelendiğinde; bir başka üst başlık olarak grup çalışmaları göze çarpmaktadır. Araştırma grubu üyeleri, grup çalışmalarına yönelik olumlu ve olumsuz ifadelerde bulunmuş ve bu ifadelere yönelik gerekçeler sunmuşlardır.

Grup üyelerinin birbirleri ile etkileşimli bir biçimde gerçekleştirdikleri alan çalışmalarına yönelik yaşamış oldukları çatışmaların ve sorumluluk paylaşımlarının kimi zaman grup üyelerinin motivasyonunu olumsuz bir biçimde etkilediği gözlemlenmiştir. Bu bağlamda grup çatışmalarına yönelik öne çıkan görüşler şu biçimdedir:

K12: Mesela en son yaptığımız Cermodern ve Salt Ulus gezisinden başlamak istiyorum. Öncesinde gidecek kişilerin uygun olduğu saatler belirlenmişti ve itirazda bulunan olmamıştı 
ama gitmeden bir gün öncesinde gruba yazdığımda herkesin bir işi çıkmıştı ve sanki sormasaydık hiç söylemeyecek gibilerdi gerçi sormamıza rağmen hiçbir şey demeyenlerde vardı ve bu beni açıkçası çok kızdırmıştı.

K19: Bu konuda en büyük dezavantajımız bence ekip üyelerinin birbiriyle fazla samimi olması, böyle olduğu için "İlla gruptan biri yapar" diyerek herkesin birbirine sorumluluğu attı̆̆ını ve aksattığımızı düşünüyorum.

Araştırma grubu üyelerinin birbirileri ile olan iletişimini olumsuz etkileyen bu tür sorumluluk üstlenme durumlarının, özellikle çalışmanın sonlarına doğru daha yoğun bir biçimde kendini gösterdiği gözlemlenmiştir. Grup çalışmalarında gözlemlenen bir diğer olumsuz tema ise grup üyeleri ile ortak yollar üretmenin zorluluğu başlı̆̆ında toplanmıştır. Dramatik açıdan incelendiğinde çözümlenmesi gereken bir problem durumu yaratan bu anlaşmazlıklar araştırma grubu üyelerinin belirgin gerilimleri arasında yer almaktadır. Bu başlıkta öne çıkan katılımcı görüşleri ise şu biçimde ifade edilmiştir:

K3: Grup arkadaşlarımın en basitinden koltuk rengini belirlerken bile kendi istedikleri kabul edilmediğinde çalışmaya olan motivelerinin o gün içinde düştüğünü gözlemleyebiliyordum. Orta yolu bulmaya çalışmak böyle durumlarda bazen beni yoruyordu.

K6: En çok sıkıntı yaşadığım nokta grupla birlikte bir şeyler yapma zorunluluğu hissetmiş olmamdı aslında ortak bir yerde buluşamıyorsak teker teker alana çıkı sonra bunları birleştirerek bir ortak noktaya varılabilirdi.

Araştırma grubu üyelerinin bir diğer olumsuz duyguya evrildiği başlık ise küçük gruplarla çalışma durumudur. Uzman mantosu sürecinde bir çok çalışmada birlikte üretimlerde bulunan araştırma grubu üyeleri, komisyon model uygulamalarında çok fazla bölüme odaklandıkları için küçük gruplar halinde çalışmalarını sürdürmüşlerdir. Daha önceden tüm grupla yapılan çalışmalarda kendilerini daha iyi hisseden bazı araştırma grubu üyeleri, diğer küçük grupların motivasyonlarını ve elemanlarını kendi motivasyonları ve grup elemanları ile karşılaştırmaya başlamışlardır. $\mathrm{Bu}$ bağlamda oluşan yeni küçük grupların işleyişine ilişkin eleştirel ifadelerde bulunmuşlardır.

K8: Çalışma salonunu tasarlarken bir süre sonra yeni şeyler üretemediğimizi fark ettim. Bunun nedenini de yine az kişi olmamıza ve aynı şeylerle uğraştığımız için hayal gücümüzün tükendiğine inanıyorum. Keşke çalışma esnasında ara ara grup değişikliği yapsaydık diyorum. Bunun bizim hayal gücümüzü canlı tutacağına inanıyorum.

K9: Komisyon çalışmasına kendi öznelim dışında bakmam gerekirse EYAT' ın enerjisini düşüren zamanları oldu. Bunda gruplara ayrılmamız ve birimlere ayrıldığımız gruplarla sürekli haşır neşir olmamız neden gösterebiliriz. Bu küçük grupların her birinin enerjisi aynı değildi.

Küçük grupların gerçekleştirdikleri çalışmalar; kimi grup üyeleri tarafından olumlu biçimde değerlendirilmiştir. Bu ifadeler katılımcıların kendilerine ilişkin fark ettikleri olumlu kazanımlarla beraber yorumlanmıştır. Araştırma grubu üyeleri edindikleri kazanımlar içerisinde komisyon model uygulamalarının sorumluluk bilincini geliştiren bir yaklaşım olduğu, işbirlikli öğrenmeyi sağlayan ortamlar oluşturduğu, özgüven kazandırdığı, katılımcısını değerli hissettirdiği, konuşma becerisini geliştirdiği, disiplinli-planlı çalışmayı öğrettiği ve ayrıntılı düşünmeye olanak sağladığı gibi kazanımlardan söz etmişlerdir. 
Araştırma grubu üyelerinin ifadelerinden hareketle komisyon model uygulamasının sorumluluk bilinci ürettiğine yönelik ifadelere sıkılıkla rastlanmaktadır. Bu yanı ile uzman mantosu yaklaşımı ile karşılaştırıldığında komisyon model yaklaşımının Dorothy Heathcote'un iddia ettiği biçimde daha fazla sorumluluk ürettiği sonucuna varılmıştır. Grup üyelerinden bazılarının sorumluluk üretimine yönelik ifadeleri şu biçimde göze çarpmaktadır:

K1: Komisyon çalışması disiplin, sorumluluk ve zaman gerektiriyordu. Her şeyi zamanında, işbirliği içinde yapmamız gerekiyordu. Elimden geldiğince yaptım.

K12: Bana kattı̆ğ iyi yönlerini; ortak kararlar almak ve bunları uygulayabilmek, kendini plana uygun yönlendirebilmek, sorumluluk almak, insanları alttan almaya çalışmak olarak siralayabilirim.

K19: Komisyon çalışmasının bana bu süreçte çok şey kattığını düşünüyorum. Ekip çalışmasının grup olmanın nasıl olduğu veya neler olursa ekip çalışması yapılamaz hale gelir onu öğrendim. Sorumlu birey olmanın önemli olduğunu fark ettim ve biraz bu konuda kendimde düzeltmeler yaptım.

Grup üyelerinin sorumluluk üstlenmeye yönelik ifade etmiş oldukları kazanım cümlelerinin diğer kazanım cümleleri ile karşılaştırıldığında daha sıklıkla kullanıldığı görülmektedir. Sıklıkla ifade edilen bu düşünceden hareketle, gerçek yaşam içerisinde yer alan bir problem durumunu çözmeye yönelik olarak yaşanılan durumların daha fazla sorumluluk ürettiği söylenebilir. Kişisel farklardan dolayı yaşanan grup içi çatışmaların nedenleri incelendiğinde; sorumluluk üretilmesi, paylaşılması gibi başlıklarla karşılaşılmaktadır. Disiplinli ve programlı çalışma durumları da sorumluluk üstlenme başlığ 1 ile beraber kullanılmıştır. Belirli süre içerisinde gerçekleştirilmesi gereken bir işi, işbirlikli bir biçimde küçük gruplar halinde tamamlama sorumluluğu disiplinli ve planlı çalışmayı beraberinde getirmektedir. Komisyon model çalışmalarının uygulama kuralları içerisinde yer alan; belirlenen işi zamanında teslim etme ve yayınlama durumunu disiplinli çalışmayı beraberinde getirmektedir. $\mathrm{Bu}$ bağlamda öne çıkan bazı katılımcı düşünceleri şu biçimdedir:

K3: Planlı çalışmanın önemini komisyon çalışması bana en iyi şekilde öğretti. Kendi yaşamımızdaki diğer yoğunluklar ne kadar çok da olsa planlı olursak bu çalışmaya da en iyi şekilde vakit ayırabileceğimi gördüm çünkü.

K13: Çalışmalar aslında bana bundan sonraki herhangi bir çalışmamda nasıl planlı ve programlı bir şekilde yol kat edebileceğimi gösterdi. Plan program konusunda bana katkı sağladi.

Araştırma grubu üyelerinin komisyon model uygulamalarında gerçekleştirdikleri alan çalışmaları, belirli düzeyde organizasyon becerisini önemseyen çalışmalar üzerinden yürümektedir. $\mathrm{Bu}$ nedenle çalışmalara katılan araştırma grubu üyelerinden daha fazla sorumluluk üstlenen üyelerin disiplinli olma konusunda daha belirgin tavırlar sergiledikleri gözlenmiştir. Kimi gruplarda sorumluluk alan ve planlı çalışmayı benimseyen katılımcıların diğer katılımcıları da olumlu etkiledikleri görülmüştür.

Alan çalışmalarında gerçekleşen başka insanlara temas etme durumu; grup üyelerinin tanımadıkları insanlarla iletişim kurmalarını gerektiren ortamları oluşturmuştur. $\mathrm{Bu}$ bağlamda araştırma grubu üyeleri; Ankara Üniversitesi Kültür Sanat Merkezine yönelik veri toplamaya çalışmışlar ve birçok insan ile görüşmeler gerçekleştirmişlerdir. Alan çalışmalarında veri toplamaya çalışan grup üyelerinin insanlarla gerçekleştirdikleri görüşme aşamalarının temel düzeyde; kendini 
tanıtma, çalışma amacını belirtme, soru ya da veri toplama aracını gerçek kişilerle buluşturma, yaşanan sorun ve anlaşılmama durumlarında anlık çözümler üretme, vb. gibi aşamaları içerdiği söylenebilir. Komisyon model uygulamalarının, araştırma grubu üyelerinin alan çalışmalarında özgüvenli bir biçimde iletişim kurmalarını sağladığg söylenebilir.

K3: Kişilerarası ilişkilerimde, konuşma becerimde dahi komisyon çalışmasının bir sürü etkisi oldu. Normalde tanımadığım insanlarla konuşmak, onları beni dinlemeye yöneltmek benim için zor bir şey iken komisyon çalışmasında alana indiğimde kendimde bu konuda olumlu değişmeler gördüm.

K4: Ben ilk kez bir insanı durdurup sorular sormak için izin isteyecektim ve nasıl bir tepkiyle karşılaşacağımı bilmediğim için biraz çekingendim. Neyse en sonunda bir cesaret yapabileceğimiz insanları gözümüze kestirip gittik. Ve anket yaptığımız nerdeyse bütün insanlar çok tatlıdı ve bizi hiç kırmadılar.

K16: Çalışmanın getirileri oldukça fazlaydı. Öncelikle alana çıktığımızda kişiler arası ilişkiler olarak geliştirdiğimiz yönler oldu. Bazen hiç tanımadığımız ne tepki vereceğini bilmediğimiz kişilerle konuştuk, ses kaydı, video fotoğraf rica ettik. Çok büyük sıkıntılarla karşılaşmadık.

Komisyon model çalışmalarının araştırma grubu üyeleri tarafından değerlendirilmesi sonucunda ortaya çıkan başlıklardan bir diğeri de araştırma grubu üyelerinin kendilerini değerli hissettiklerine ilişkindir. Bu doğrultuda grup üyeleri; alan çalışmalarında kendilerine verilen tepkiler ve uzman kişilerin çalışmaya yönelik cümlelerinden hareketle değerli hissettiklerini belirtmişlerdir.

K4: Böyle bir çalışmada yer aldığım için kendimi değerli hissediyorum çünkü fikirlerimiz önemseniyordu. Dolu dolu bir sene geçirdik ve her aşamasında çok güzel işler çıkarttı̆̆ımızı düşünüyorum.

K5: Bundan sonra rektörümüz ile görüşmeye gittik. Bu görüşmeye gitmek beni gerçekten çok mutlu etti, iyi ki ben de gidebildim dedim. Bu konuşma bana birçok şey kattı. Kültür evine nasıl baktığını, neler düşündügünü öğrendik. Rektör bey ile görüştükten sonra kendimi önemli hissettim. Rektör beyle konuştuklarımızı diğer arkadaşlarımızı da aktardık.

K9: Tüm bunların yanında bir yöneticinin tüm düşüncelerimizi ilgiyle dinlemesi, fikirlerimizi çok önemsemesi bana kendimi çok iyi hissettirdi.

Grup üyelerinin komisyon model uygulaması süresince gerçekleştirmiş oldukları etkinliklere yönelik duydukları bu hisler çalışmaya olan inançlarını arttırmıştır. Öğrencilerin yaptıkları işler, temas ettikleri insanlar ve uzmanlar, ürettikleri düşünceler, bu hislerden olumlu bir biçimde etkilenmiş ve daha nitelikli süreçler yaşamalarını sağlamıştır. Grup üyelerinin yaptıkları işlerin onay alması ve takdir görmesi çalışmayı sahiplenmelerini sağlamıştır.

Araştırma grubu üyelerinin ortaya koymuş olduğu bu düşünceler, komisyon model uygulamalarının katılımcısını değerli hissettiren bir yapıya sahip olduğunu göstermektedir. Kendisini değerli hisseden katılımcının yapmış olduğu işe daha fazla sahip çıktığı gözlemlenmiştir. İşine sahip çıkan grup üyeleri çalışma süresince sorumluluk üstlendiklerini ifade etmişlerdir. Üstlenilen bu sorumluluk, grup üyelerinin daha planlı ve özenli çalışmasına katkıda bulunmuştur. Araştırma grubunun sözel ifade becerilerini de olumlu bir biçimde etkileyen komisyon model uygulamaları; gerçek yaşam ile temas noktasında, ayrıntılı çalışmaların uygulanmasına olanak sağlamıştır. 
Komisyon model uygulamalarının katılımcısında yarattığı izlenim incelendiğinde; grup üyelerinin kendilerini değerli hissettikleri temas alanlarının oluştuğu gözlemlenmişsir. Ankara Üniversitesi Kültür Sanat Merkezi binasının yapımına katkı sağladığı düşünen araştırma grubu üyeleri; uzmanlarla gerçekleştirdikleri görüşmeler ve alan çalışmalarının ardından kendileri gibi davrandıkları gerçekçi durumlar üzerinden, gerçekçi duygular geliştirmişlerdir. Grup üyelerinin birbirleri ile yaşadıkları yakın iletişim problemlerinin yaratmış olduğu olumsuz duygular ve zaman zaman süreçten sıkılma durumlarının dışında, gerçekleştirilen tüm alan çalışmalarının sunmuş olduğu diğer ortam ve temasların yoğunlukla grubu motive edici bir duygu yarattığı gözlemlenmiştir. Araştırma grubu üyelerinin ifadelerinden hareketle komisyon modele yönelik oluşturulan veri analizlerinin haritalandırılması şu biçimde oluşmuş̧ur :

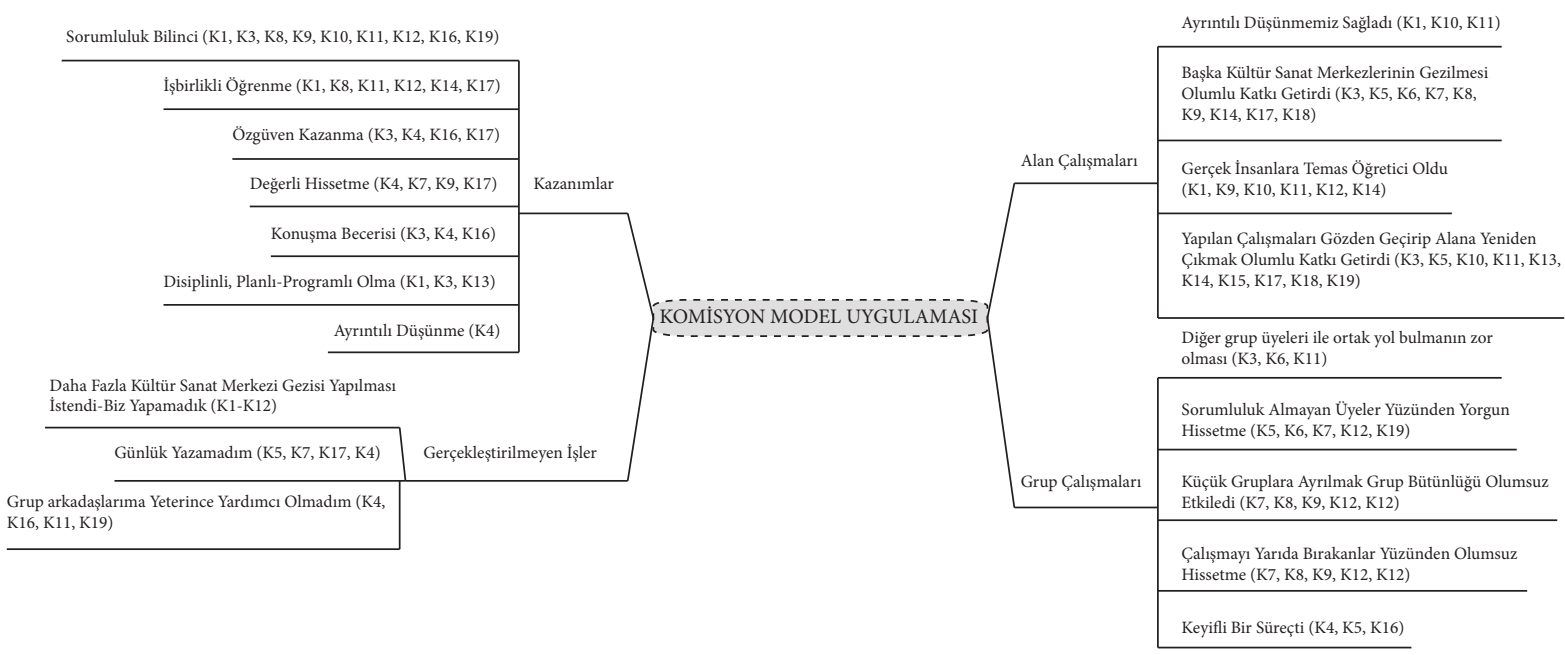

Şekil 3: Araştırma Grubu Üyelerinin Komisyon Model Uygulamasına Yönelik Düşünceleri

\section{Odak Grup Görüşmelerimiz Eksik Kalan Duygu ve Düşüncelerimizi Tamamlıyor}

Grup üyelerinin araştırma sürecinde yaşamış oldukları durumlar ve bu durumların oluşturduğu duygu durumlarına ilişkin verileri ortaya koymak amacıyla rastgele oluşturulan küçük gruplarla odak grup görüşmeleri gerçekleştirilmiştir. Bu bağlamda üç farklı grup oluşturulmuş ve bu gruplarla yarı yapılandırılmış sorular üzerinden odak grup görüşmeleri tamamlanmıştır.

Odak grup görüşmeleri verilerinin analizinin ardından ortaya çıkan temalar; çalışma sürecinin özetleyen yazıların ardından oluşan temalar ile benzerlikler göstermektedir. Araştırmacı tarafından grup üyelerine yönlendirilen sorular da bu temaların oluşmasında belirleyici olmuştur. Araştırma grubu üyelerinin genel olarak vermiş olduğu yanıtlar; "uzman mantosu" uygulaması ve "komisyon model" üst başlıklarını ayrıntılandıracak belirlemeleri içermektedir.

Araştırma sürecine katkı sağlayan grup üyelerinden sadece bir kişi odak grup görüşmesine katılamamıştır. Bununla beraber alan çalışmalarına ilişkin görüşlerini özetlemeyen fakat sürece katkıda bulunan üç grup üyesi de odak grup görüşmesine katılmıştır. Odak grup görüşmesinin ardından oluşan temalar, grup üyelerinin yazmış oldukları özet çalışmaları ile benzerlik gösterdiğinden; araştırmanın o bölümünde yer alan bulgu ve yorumlarda tekrarlar oluşmuştur. Bu bağlamda araştırma verilerinin belirli bir doygunluğa ulaştığı söylenebilir. Bu nedenle odak grup görüşmelerinde sunulan verilere öz bir biçimde yer verilmiştir. 
Araştırma grubu üyeleri ile gerçekleştirilen odak grup görüşmesinde öne çıkan önemli başlıklardan biri uzman mantosu ve komisyon model uygulamalarında üstlenilen rollere ilişkindir. Grup üyeleri kendi yaşantılarından hareketle nerede rol içerisinde oldukları, nerede rolün dışına çıktıklarına ilişkin belirlemelerde bulunmuşlardır. Bu bağlamda araştırma grubu üyelerinin "rol" kavramına yönelik öne çıkan düşünceleri şu biçimdedir :

K16: Uzman mantosunda sadece rolde gibi hissettim ben mesela isimliklerin takılmas1. Orada herkesin birbirine hiç tanımıyormuş gibi, aynı yerde çalışan kişilermiş ciddiyetiyle o ortam oluşturulmuştu gerçekten o zaman bayağı bir rolün içerisinde hissediyordum kendimi...

K12: benim için bu özgürlük rolden daha çok tam böyle her şeyin en güzeli yapabileceğimin en iyisi şeklinde değil de zaten daha önce hayalini kurduğum bir odayı yapmak istemiştim ama bunu yaparken cidden sunum yaparken falan gerçekten o role girmiştim artık rol ile gerçeği ayırt edemiyordum...

K:17: Evet rolde, bir role bürünmedim ben ne diyorsam onu anlattım. Sanki bu işin eri zaten benmiş̧im gibi. Öyleydim, öğrenciydim, öğrenci olarak anlattım. Zaten diyoruz bize böyle bir görev verildi, biz de bunu üstlendik ve hani Kültür ve Sanat Merkezi'nin drama ve dans salonunu tasarlıyoruz. Biz öğrencileriz gibisinden açıklama yapıyoruz anlatmaya başlarken.

K22: Bence rol yaparken bile, bende çok karışıktı aslında hani kendimizken de rol yapıyorduk mesela müzik benim ilgi duyduğum bir alan kesinlikle aslında çok da severim ama sonuçta hiçbirimiz öyle bir şey de bulunmadık, hiçbir zaman da bir müzik odası hazırlamadım o yüzden sanki hayaldi ve sanki uzmanmış gibi davranıyorduk falan bir şekilde kendimizdik ama roldeydik yani uzman olan kendimiz. Gerçekçi bir hayaldi.

Yukarıda yer alan ifadeler uzman mantosu ve komisyon model uygulamalarında grup üyelerinin rol sınırlarına ilişkin değişimler (rol içerisine girmeler ve çıkmalar) yaşadıklarını göstermektedir. Özellikle K22'nin belirtmiş olduğu durum Dorothy Heathcote'un “Alacakaranlık Rol” adını verdiği ve gerçek ile kurgunun birbirine karıştığı durumlara örnek oluşturmaktadır. Katılımcılar özellikle uzman mantosu uygulama süreci içerisinde rol içerisinde oldukları durumlara ve rolde olmayıp kendileri gibi davrandıkları durumlara ilişkin betimlemelerde bulunmuşlardır. Uzman mantosu süreçlerinin düş kurma süreçlerinden beslendiği, etkinlikler yolu ile bu düş kurma durumlarının gerçekçi duygu, düşünce ve tepkileri oluşturduğu görülmektedir. Bu nedenle araştırma grubu üyeleri, rol üstlendikleri anda kendileri gibi olduklarını ve doğal bir davranış sergilediklerini ifade etmişlerdir. Bu ifadelerden hareketle uzman mantosu ve komisyon çalışmalarında yer alan "rol” kavramının gerçek yaşam tepkileri ile benzeştiği görülmektedir.

Araştırma grubu ile gerçekleştirilen odak grup görüşmesi sonrasında ortaya çıkan başlıklardan bir diğeri ise komisyon model uygulamasının sorumluluk üreten bir yaklaşım olduğuna ilişkindir. Araştırma grubu üyeleri; komisyon model uygulaması içerisinde gerçekleştirmiş oldukları etkinliklere ilişkin sorumluluk duyduklarını, bu nedenle Kültür Sanat Merkezi binasının yapımını sahiplendiklerini ifade etmişlerdir. Bununla beraber, sorumluluk üstlenme durumlarının grup üyelerinin kişisel gelişimlerine de katkı sağladığı görülmektedir.

K3: Evet komisyon çalışması çok uzun sürdü ve bizim aslında direkt sorumluluklar almamız gereken bir süreçti. Bana göre bu sorumluluk bilincini ve yaratıcılığı çok yüksek tutan bir şeydi. Benim sorumluluk bilincimden çok kendi sorumluluk bilincimden çok grup arkadaşlarımızın sorumluluk bilinci almaması etkiledi. 
K7: Alana çıktığımız zamanda komisyon çalışması başladığında sorumluluk almamız gerekti, daha bir işin içine girdiğimiz ve daha gerçekçi, büyük bir şey yaptığımızı fark ettik. O biraz bana iyi gelmişti. Büyüdüğümü hissettirdi gibi bir şey. Bir insan sana bir sorumluluk veriyor.

K18: Ama böyle anlatırken anlatırken projeyi çok garip hissediyordum. Komisyon çalışması sorumluluk alma bakımından daha olumlu bir etki biraktı.

K21: Komisyon çalışması gerçekten bize büyük sorumluluklaryükledi, en sorumsuzlarımızdan biri bendim komisyon çalışmasında. Çünkü alana çıkmada gerçekten biz grubumuzdan sıkıntılar yaşıyorduk, bir araya gelemiyorduk, bunlara rağmen gerçekten bize de sorumluluk bilincini aşı1ladı.

Yukarıda yer alan ifadelerden hareketle komisyon model uygulamasının, sorumluluk üretme ve bu sorumluluktan hareketle bilgiye ulaşma isteği uyandırdığg görülmektedir.

Odak grup görüşmelerinde ortaya çıkan bir diğer başlık ise; gerçek yaşam durumlarının, eğitim aracı olmasının, çalışma motivasyonunu genel olarak katılımcıları olumlu etkilediğine ilişkindir. Araştırma sürecinde uzmanlar ve diğer insanlarla gerçekleştirilen temaslar; grup üyelerinin kişisel gelimi ve çalışmaya ilişkin motivasyonlarını olumlu bir biçimde etkilemiştir. Bu başlık altında, grup üyelerinin öne çıkan görüşleri şu biçimdedir:

K4: Bana en iyi gelen kısmı; mimar Özlem Hanım ile gezerken hani kadın bir şaşkındı. Yani onları düşündüğümüze ya da onları yapabildiğimize... Hatta çıkışta da söyledi herhalde. Tam olarak hatırlamıyorum ama siz burada proje hazırlamışsınız. Bu nasıl tanımlanır. Yani şaşkındı, onun belki de üniversite öğrencisi olduğumuz için olabilir. Bu binayı sonuçta biz baştan tasarladık. Bu onun işiydi ve biz bunu yapabildik.

K9: Özellikle günlüklerimde de bahsettiğim Siyasal Bilgiler Fakültesinde görüşmeye gittiğimizde amcanın o kadar yardım etmek istemesi ya da kültür evindeki kişinin bizimle çok ilgilenmesi, bizim fikirlerimizi önemsemesi, bir şeylere katkı sağlamak istemesi belki bana insani değerler anlamında da çok şey kattı.

K14: Ankara Üniversitesi Kültür Şube Müdürü Şükrü Bey ile görüşmek, mimar Özlem Hanım ile görüşmek çok iyiydi benim için. Bu kırılan inancımızı daha çok toparlamaya yardımcı oldu. Belli bir noktasında çalışmayı sahiplendik.

Bu başlık altında, araştırma grubu üyelerinin kendi süreçlerini özetledikleri metinlerde ortaya çıkan verilere koşut verileri betimlediği görülmektedir. Uzmanlar, karar vericiler ve paydaşlarla temas etmenin; çalışmayı sahiplenme ve bir sonraki çalışma adımını belirleme konusunda belirleyici olduğu görülmektedir. Gerçek duyguların, gerçek yaşantıların ve gerçek tepkilerin çalışmaya yönelik sorumluluk ürettiği söylenebilir.

Grup üyelerinin kendi aralarında yaşamış oldukları iletişim sorunları ise motivasyonu azaltan yaşantılar olarak görülmektedir. Çalışmaya ilişkin bireysel olarak sunulan özetleme ve betimleme metinlerinde de sıklıkla karşılaşılan bu durum, var olan sorumluluk paylaşımında ortaya çıkan gerçekçi duygular olarak görülmektedir. Motivasyonlarını olumsuz yönde etkileyen ifadeleri özenli bir biçimde dile getiren grup üyelerinden bazıları; sıklıkla küçük grup çalışmaları ile gerçekleştirilen etkinliklerin daha büyük gruplar halinde gerçekleştirilmesi gerektiğinden söz etmişlerdir.

K3: Bütün eyat, bütün o topluluk burada her akşam geliyorduk mesela ama herkes kendi çalışmasını yapıyordu ya da ne bileyim herkes kendi anketini doldurmaya gidiyordu vesaire 
gibi. Bu biraz daha böyle bizim komisyon çalışmasında verdiğimiz, gösterdiğimiz heyecanı azalttı gibi geliyor bana

K12: Bence komisyon çalışmasının avantaj olarak kazandırdığı bir şey olarak hepimizin söylediği bir şey; grup bilinci aşıladı ama bence bu aslında dezavantaj olarak geldi bizim eyat olarak tümüne bakarsak. Çünkü herkesin belli bir grubu vardı. İlk baştaki grupları uzman mantosunda farklıydı, komisyon çalışmasında farklılaştı. Yine arada gidiş gelişler oldu ve alana çıkarken herkes sadece kendi grubu ile çıktı, kendi grubu ile anlaşamayan insanlar da oldu.

Araştırma grubunun tercih ettiği veri toplama araçlarının başında kendi geliştirdikleri anketler yer almaktadır. Alan çalışmalarında grup üyelerinin anket uygulamasını tercih etmelerinin gerekçeleri arasında ortak sorularla hareket etme isteğinin yer aldığ 1 görülmektedir. Aynı küçük grup içerisinde yer alan farklı üyeler; alan çalışmalarında kimi zaman birbirlerinden ayrı biçimde hareket etmiş̧lerdir. Grup üyeleri, oluşan bu ayrıksılı̆̆ı olabildiğince aynı soruları sorarak gidermeye çalışmışlardır. Bu veri toplama biçiminin tercih edilmesi ile grup üyelerinin anket uygulamaya ilişkin kaygılarını azaltmaya çalıştıkları düşünülmektedir.

Grup üyeleri ile gerçekleştirilen odak grup görüşmeleri, onların alan çalışmalarına ilişkin görüş ve yaşantılarını ortaya koymuştur. Odak grup görüşmesine katılan grup üyeleri birbirlerine yaşantıları ile ilgili durumlara yönelik anımsatmalarda bulunarak çeşitli konu başlıklarına ilişkin veri paylaşılmasına olanak sağlamışlardır. Özet çalışmalarında ayrıntılandırılan bir çok tema, odak grup görüşmelerinin ardından da ortaya çıkmıştır. Benzeşen bu temalardan hareketle, odak grup görüşmelerinin diğer veri toplama araçları ile toplanan verileri desteklediği söylenebilir. Veri çeşitlemesi yapılarak daha güvenilir bir sonuca ulaşılmış ve grup üyelerinin komisyon modele ilişkin düşünceleri ayrıntılandırılmıştır. Odak grup görüşmesi verilerinin analizinin ardından çalışmaya ilişkin tüm verilerin bulgu ve yorumları sonlandırılmıştır.

\section{Tartışma, Sonuç ve Öneriler}

Araştırmanın bu aşamasında, doğal bir biçimde akan yaşamı değiştirmeden, sosyal etkileşim yolu ile duyuşsal ve bilişsel kazanımlara ulaşılmaya çalışılmıştır. Komisyon model uygulaması boyunca devam eden etkinlikler bir sahneleme süreci gibi düşünüldüğünde, her grup üyesi bütün bir performansın belirli küçük performatif oyuncuları olmuşlardır. Bu bağlamda uygulama süreci; grup üyelerinin eylemde bulundukları anlar, oluşan etkileşimler, yaşanılan kaygılar, tercih edilen yöntemler gibi birçok durum üzerinden sorgulanacak ortamları içermektedir. Doğal bir ortam içerisinde, kendi seçim ve tepkileri ile komisyon model uygulaması etkinliklerine yön veren grup üyeleri; sosyal etkileşimlerde bulundukları için değişken sayılabilecek duygu durumları ve kazanımlara tanık olmuşlardır.

Bulundukları sosyal yapı içerisinde birbirleri ve alanda yer alan insanlar ile etki ve tepki alışverişinde bulunan araştırma grubu üyeleri, doğal sayılabilecek bir biçimde araştırma sürecine dahil olmuşlardır.

Alışılagelmiş eğitim ortamları, öğrencilerin belirli hareketler, tavır ve tepkiler sergiledikleri, belirli kurallar ile çerçevelenmiş bir set oluşturmaktadır. Bununla beraber öğrenci grubunun kendini daha rahat hissettiği ortamlar katı kurallar ile çerçevelenmediğinden daha gerçekçi ve doğal 
etkileşimleri içermektedir. Sözgelimi bu çalışma özelinde, alan çalı̧̧malarına çıkan grup üyeleri kendilerini daha rahat hissettikleri ortamlardan veri toplamaya çalışmışlardır. Bu ortamlarda grup üyeleri, istedikleri ve hazır hissettikleri zamanlarda diğer paydaşlar ile etkileşimde bulunmuşlar, istedikleri zamanda da etkinliği sonlandırmışlardır. Sosyal statü olarak; deneyim, cinsiyet, fakülte bölümü vb. noktalardan farklı seviyede bulunan grup üyeleri, kendi aralarında herhangi bir biçimde yaptırım oluşturacak kurallar belirlememişlerdir. Bireysel farklılıklar, çalışmaya ilişkin motivasyonu ve grup üyelerinin duygu durumlarını etkilemiştir. Araştırmacı, komisyon model uygulaması süresince olabildiğince "öğretmen" sözcüğünün kendiliğinden getirdiği hiyerarşik yapıyı hissettirmemek adına rehber görevi üstlenip, doğrudan karar verme süreçlerini grup üyelerine bırakmıştır. Buna rağmen; grup üyeleri ve araştırmacı arasında oluşan önceki kodların hiyerarşik düşünceden yeterince sıyrılamadığı gözlemlenmiştir.

Komisyon model uygulaması rol ve gerçeklik kavramlarının karıştığı bir uygulama sürecini içermektedir. Çalışma sürecinde grup üyeleri, küçük gruplar halinde çalışmalar yürüterek, bireysel gelişim süreçleri göstermişlerdir. Çalışma kapsamında komisyon model uygulaması içerisinde gerçekleştirilen grup çalışmalarının genellikle olumlu bir motivasyon ürettiği sonucuna varılmıştır. Bununla beraber görev odaklı çalışmalarda yeterince sorumluluk üstlenmeyen öğrencilerin ise diğer grup üyelerinin motivasyonunu olumsuz etkilediği görülmüştür. Dramaturjik yaklaşım ile dünyanın bir sahne olduğunu söyleyen Erving Goffmann'ın, “takım” adını verdiği etkileşimli yaratımlar ve bu yaratımlarda bireylerin vermiş olduğu tepkilere ilişkin görüşleri şu biçimdedir:

Aynı takımın üyeleri olan bu bireylerin sırf takımdaşlık nedeniyle birbirleriyle önemli bir ilişki içinde olacakları açıktır. Bu ilişkinin iki temel bileşeninden söz edebiliriz. Birinci olarak, öyle görünüyor ki takım performansı bir yandan devam ederken, takımın herhangi bir üyesi gösterinin foyasını meydana çıkarma ya da uygunsuz davranışlarla performansı azaltma gücüne sahiptir. Tüm takım arkadaşları birbirlerinin hareket ve davranışlarına güvenmek zorundadırlar. Buna göre, takım arkadaşlarını birbirlerine bağlayan karşılıklı bir bağımlılık söz konusudur (Goffmann, 2009).

Komisyon model uygulaması süresince grup üyelerini birbirlerine bağlayan bağımlılık; yapılacak olan Kültür Sanat Merkezinin sahiplenilmesi, üretilen sorumluluk, uzmanlarla görüşülmesi ve yapılan işin ciddiyetinin kavranması gibi başlıklar yolu ile daha belirgin bir hal almıştır. Belirginleşen bu bağlayıcı duygunun, etkileşime girilen kişilerin tavır ve düşünceleri ile geliştiği söylenebilir. Takımın bir parçası olan grup üyeleri; etkileşime girdikleri kişilerden edindikleri bilgi, tepki ve düşüncelerle kendi performanslarını dönüştürmüşlerdir. Kimi grup üyeleri gerçek yaşamda yer alan ve paydaş olarak tanımlanan insanlara temas ettiği için çalışma adımlarını atmak adına iştahlanmış, kimileri ise grup arkadaşları kadar iştahlı çalışmadıkları için kendilerini sorumlu tutmuşlardır. Bu durumları oluşturan motivasyonların onlarca gerekçesi olabilir. Bütünlüklü bir yapının ayrı parçaları olarak katılımcıların yaşadıkları süreç, bireysel bir biçimde incelendiğinde; her grup üyesinin ayrı ayrı çerçeve ile sunduğu performanslarının oluşturduğu setlere ve vitrinlere bakmak gerekmektedir. Bu bağlamda grup üyelerinin iç disiplini komisyon model uygulaması için önem kazanmaktadır.

Komisyon model uygulamalarının toplum gelişimi ile de ilgili olduğu söylenebilir. Komisyon model uygulaması odağına alınan ve ortak görevlerle sonuca ulaştırılmaya çalıştırılan çalışmalar toplumda yer alan diğer paydaşların da fikirleri alınarak sonuca ulaştırılmaya çalışılmaktadır. Bu bağlamda Dorothy Heathcote'un önemsediği dramanın toplum ile ilgili olması gerekliliği 
karşılanmaktadır. Dorothy Heathcote, drama çalışmalarının toplumsal boyutu ve sanatsal boyutuna yönelik olması gerekliliğini eleştirel bir çerçeveden ele almıştır. Bu konuda kendi yaklaşımlarının da gelişme gerekçesini sunan Dorothy Heathcote așağıda yer alan ifadeleri kullanmaktadır:

“Tüm öğretim yaşamım boyunca özgünlük meselesi ile ilgili olduğunu düşündügüm iki şeye ilişkin uğraş verdim. Birincisi bir "drama öğretmeni” olarak tanımlanırken ve bu kadar açık bir biçimde işlev sağlarken insanların drama çalışmalarını sadece oyun, kurgu ve rol ile ilgili olarak algılaması beni rahatsız ediyor. Dramanın bunlarla da ilgisi var ama drama toplum için daha fazla potansiyele sahip. İkincisi ise pek çok insanın eğitim durumlarında dramanın kullanımını, ayrı bir konu olarak ya da "özel” bir mesele olarak görmesidir. Bu durumlar ile uğraşmak drama çalışmalarında sanat biçimlerini ihmal etmeme yol açmıştı. Diyagram haritaları, eskizler, fotoğraflar vb. gibi diğer üretkenlik betimlemeleri ile ilişkili bir biçimde tartışmam gerektiğini böylece farketmiş oldum"(Heathcote,1985).

Bu söylemlerden hareketle Dorothy Heathcote yaklaşımlarının bir arayış içerisinde olduğu görülmektedir. Drama çalışmalarına ilişkin oluşan ve tartışılması gereken yargıları dikkate alan Heathcote'un bu söylemleri, uzman mantosu yaklaşımının temellerini oluşturmaktadır. Drama çalışmalarında "üretkenlik betimlemeleri" olarak tanımlanan çalışmalarını önemseyen Heathcote, uzman mantosu çalışmalarında bu eksikliği giderebilecek önemlemler sunmuştur. Ardından da dramanın toplumsal boyutunu daha da ön plana çıkartan ve gerçek yaşam durumları içerisinden olabildiğince çok insana temas eden bir yaklaşım olan "Komisyon Model” uygulamasını geliştirmiştir. Araştırmanın bulgu ve yorumları dikkate alındığında komisyon model uygulamasının toplumsal boyutu önemseyen bir yaklaşım olduğun görülmektedir.

Araştırma bulgularından hareketle komisyon model yaklaşımının sorumluluk üreten, sosyal etkileşimin yoğun olduğu, gerçek yaşamda belirli rollerle gerçekleşen, doğal, öğretmenlik baskısını oluşturmayan, sanat formlarını kullanan, grup çalışmalarını sistematik bir hale getiren ve eylem adımlarının sonuçlarından hareketle yeni eylem adımları üreten bir yaklaşım olduğu sonucuna varılmıştır.

Çalışma sonunda alan uzmanlarına ve araştırmacılara yönelik şu önerilerde bulunulabilir:

- Komisyon model uygulamalarının alan yazında yeterince yer almaması nedeniyle "komisyon model” yaklaşımını tanıtmaya ve tartışmaya yönelik çalışmalar yapılabilir.

- Komisyon model yaklaşımının drama alanındaki kabul sorunu nedeniyle kurgu ve gerçeklik ilişkisinin derinlikli bir biçimde tartışılması ve bu başlık altında sosyolog, psikolog, sanatçı ve eğitimcileri bir araya getirebilecek etkinlikler düzenlenebilir.

- Drama çalışmaları daha çok sosyal etkileşimi ve toplumsal değişimi önemseyen bir biçimde yapılandırılılmalıdır.

- Drama çalışmaları gerçek yaşama temas eden boyutları arttırılmalıdır.

- Komisyon model uygulamalarının az olması nedeniyle yeni istemciler bulunarak komisyon model uygulamalarının arttırılması önerilmektedir. 


\section{Kaynakça}

Bayad, A. (2016). Erving Goffman'ın benlik kavramı ve insan doğası varsayımı. Psikoloji Çalışmaları Dergisi. 36(1), 65-80.

Creswell, J. W. (2013). Nitel araştırma yöntemleri beş yaklaşıma göre nitel araştırma ve araştırma deseni. Ankara: Siyasal Kitabevi.

Dewey, J. (1996). Democracy and education. (Çev. Otaran, M.S.) Ankara: Başarı Kültür Yayınları Dizisi

Ekiz, D. (2009). Bilimsel araştırma yöntemleri. Ankara: Anı Yayıncılık.

Eriksson, S. A. (2009). Distancing at close range. ABO Akademi.

Fiala, O. (1977). "An artistic affinity. Notes on Dorothy Heathcote's and Bertolt Brecht's modes of work". National Association of Drama in Education Journal. 2(1), 29-32.

Goffman, E. (2009). Günlük yaşamda benliğin sunumu. İstanbul: Metis Yayınları.

Heathcote, D. (1985). Improvisation. In Dorothy Heathcote: Collected writings on education and drama, (ed. Liz Johnson and Cecily O'Neill), 44_8. London: Hutchinson.

Hesten, S. (1993). The Dorothy Heathcote Archive (Doctoral Dissertation). Manchester, Metropolitan University.

Kuzu, A. (2005). Oluşturmacılı̆̆a dayalı çevirimiçi destekli öğretim: Bir eylem araştırması (Yayımlanmamış Doktora Tezi). Eskişehir Anadolu Üniversitesi, Eskişehir.

Metinnam, İ., Adıgüzel, Ö. (2016). "Bireyin bireyselliği” odağında Brian Way’in drama anlayışının incelenmesi. Yaratıcı Drama Dergisi. 11(2), 1-28.

Schön, D. A. (1983) The reflective practitioner: how professionals think in action. San Francisco: Ca, Jossey-Bass.

Tor, H. A. (2008). A comparative analysis of the relationship between dramaturgy and epistemology in the praxis of Gavin Bolton and Dorothy Heathcote. Research in Drama Education:The Journal of Applied Theatre and Performance. 13(3), 321-335.

Özen, Z. (2011). Dorothy Heathcote'un yaratıcı drama yaklaşımları (Yayımlanmamış Yüksek Lisans Tezi). Ankara Üniversitesi, Ankara.

Yıldırım, A., Şimşek, H. (2013). Sosyal bilimlerde nitel araştırma yöntemleri (9. Baskl). Ankara: Seçkin Yayınları. 